\title{
Hormonal Regulation of Fish Adaptation to Atypical Fluctuations in Temperature and Oxygen Regime of a Water Body
}

\author{
Oleksandr Potrokhov, Oleg Zinkovskyi, Mykola Prychepa, Yurii Khudiiash
}

Department of fish reproduction biology, Institute of Hydrobiology NA of Science, Ukraine, Pr. Geroyiv Stalingrada, 12, Kyiv-210, 04210, Ukraine, Tel.: +0380-66-514-56-00, E-mail: alport@bigmir.net, olzinkovskyi@gmail.com, prichepa1987@ukr.net, yurahud@ukr.net

Oleksandr Potrokhov (Corresponding author)

Department of fish reproduction biology, Institute of Hydrobiology NA of Science, Ukraine, Pr. Geroyiv Stalingrada, 12, Kyiv-210, 04210, Ukraine, Tel.: +0380-66-514-56-00, E-mail: alport@bigmir.net

Received: March 1, 2019 Accepted: March 27, 2019 Published: March 31, 2019

doi:10.5296/ast.v7i2.14444 URL: https://doi.org/10.5296/ast.v7i2.14444

\begin{abstract}
Recently, the water temperature significantly exceeded the climatic norms for the studied region of Ukraine. Water is heated to $30^{\circ} \mathrm{C}$ with a decrease in the concentration of dissolved oxygen in shallow water. In this connection, the change in the hormone content in the blood plasma of carp, roach, rudd, perch and ruff in response to these factors has been studied. Most of the fish species studied in June respond by increasing the cortisol content in the blood by 1.2-3.3 times to an increase in water temperature. Fish quite successfully adapts after a month's stay in conditions of high water temperature to $31^{\circ} \mathrm{C}$, and the level of cortisol is reduced. The content of thyroid hormones in the blood of the rudd, roach and ruff is quite high and after a month of adaptation to the existing factors. This indicates an increased activity in their metabolic processes. The content of somatotropin and prolactin in the blood of the studied fish species decreases 2.4-5.0 and 1.9-7.7 times, respectively, in response to an increase in temperature and a decrease in the oxygen concentration in water. This should lead to a decrease in the rate of fish growth and change in the activity of osmotic exchange. However, hormonal reactions are species-specific in nature to the existing factors. Perch and roach are less plastic to increase water temperature. Carp most favorably tolerates an increase in water temperature and a decrease in oxygen concentration.
\end{abstract}

Keywords: hormone, fish, temperature, oxygen, metabolism, adaptation 


\section{Introduction}

Aquatic organisms are constantly exposed to various environmental factors (Nemova \& Vysotskaya 2004). Recently, the trend of global warming has significantly affected aquatic organisms (Comte \& Olden 2017). The processes of eutrophication of water bodies increase with an abnormal increase in water temperature in the summer. At the same time, primary production in reservoirs may increase even in the absence of nutrient inputs. (Rui Xia et al. 2016). Climatic anomalies lead to large-scale transformations of ecosystems under conditions of increasing anthropogenic pressure (Ogorodnikova et al. 2004). Temperature is one of the main limiting factors for the growth and development of hydrobionts. Changes in the thermal and hydrochemical characteristics of water bodies determine the physiological state of the organisms (Jobling 1981).

The effect of minor temperature fluctuations on the body of aquatic organisms is noted in many studies. Temperature has a significant impact on all levels of the structural organization of aquatic organisms. This is especially important for exothermic organisms, including fish. They are convenient model objects for studying the mechanisms of thermoadaptation (Goldspink 1995, Nemova \& Vysotskaya 2004).

Fish are sensitive indicators of stress. The change in their physiological and biochemical parameters reflects the hydroecological situation of the water bodies. The lifespan, size and resistance of fish to the sublethal effects of stressors make it possible to use them as biomarkers of the ecological state of the reservoir. The physiological and biochemical parameters of fish reflect the complex adverse effects of the aquatic environment (Nemova \& Vysotskaya 2004).

The effect of cyclic temperature changes on different aspects of the ectotherm biology has been the subject of many studies (Klyashtorin \& Lyubushin 2007, Yadav 2008). However, the effects of arrhythmic temperature changes have rarely been studied. It is known that organisms can undergo rapid and sometimes unpredictable temperature fluctuations in both natural and anthropogenically modified aquatic systems. This applies to pelagic organisms during their daily diurnal vertical migrations and to littoral organisms that are subject to significant daily fluctuations in temperature (Malinin et al. 1996). Obviously, such a stimulating effect can occur not only with cyclical fluctuations, but also with one-time, stepwise temperature changes (abrupt warming up or cooling of water) (Konstantinov et al. 2003).

Reactions to harsh, non-cyclical effects of temperature have not been studied for most of the dominant fish species. The values of the upper limit of the temperature tolerance are not defined. The change in physiological reactions in fish under temperature conditions has also not been sufficiently studied. The reactions of the organism / population continue to manifest themselves after the completion of the influence of the temperature factor, which is also currently little studied.

The temperature factor that regulates all life cycles of hydrobionts has always attracted and continues to attract the attention of researchers of various specialties. In connection with this, 
the problems of studying the temperature norm, the consequences of temperature stress (Vinagrea et al. 2012), thermotolerance (Lund \& Tufts 2003), the mechanisms of temperature perception and the strategy of thermoregulation remain of relevance. An important place in the range of these problems is the establishment of the values of the temperature optimum and the boundaries of tolerance of species (Handeland et al 2008).

It is known that each species of fish has its optimal range of temperatures for life, in which they are most active (for the vast majority it is $15-24^{\circ} \mathrm{C}$ ). Scientists observe changes in physiological reactions beyond the optimum temperature, and in particular the inhibition of certain functions (Nilsson \& Lefevre 2016).

Changes in the hydrological and hydrochemical regime of water bodies are the main factors determining the normal or stressful state of the fish. The fish neurohumoral system determines the functioning of various processes during dynamic changes in aquatic ecosystems. The timely transmission of signals from the neurohumoral system adequately regulates the physiological state of the fish during changes (sometimes critical) in environmental conditions (McCormick \& Bradshaw 2006, McCormick 2011, Little et al. 2013).

\section{Material and Methods}

\subsection{Object of Research}

Carp Cyprinus carpio Linnaeus, rudd Scardinis erythrophthalmus Linnaeus, roach Rutilus rutilus Linnaeus, perch Perca fluviatilis Linnaeus and ruff Gymnocephalus cernuus Linnaeus were investigated. The mass and zoological length of carp were 100-150 g, 20-25 cm; rudd $30-40 \mathrm{~g}, 10-12 \mathrm{~cm}$; roach - 40-50 g, 10-15 cm; perch - 50-60 g, 12-15 cm; ruff - 20-25 g, $10-14 \mathrm{~cm}$. Age of fish was 2--3 years. It is known that the rudd lives in the surface layers of water; carp, perch and roach - in the water column or its bottom layers; ruff - in the bottom layers of water (Movchan 2011). The fish were placed in experimental water bodies in April 2017.

\subsection{Experimental Water Reservoirs}

The research was carried out on four water bodies. No. 1 is a small storage reservoir on the Ros river (Kyiv region, Ukraine). The water temperature fluctuated in the reservoir in June from 20.3 to $23.5^{\circ} \mathrm{C}$ (on average $-21.8^{\circ} \mathrm{C}$ ), in July $-20.2-25.2^{\circ} \mathrm{C}\left(23.3^{\circ} \mathrm{C}\right.$ ) (Fig. 1). Fluctuations in water temperature during the day did not exceed $1^{\circ} \mathrm{C}$. The temperature regime of this reservoir was accepted for conditional control. It did not exceed the climatic norms for the investigated region of Ukraine. The depth of the reservoir reached 5-7 m. 

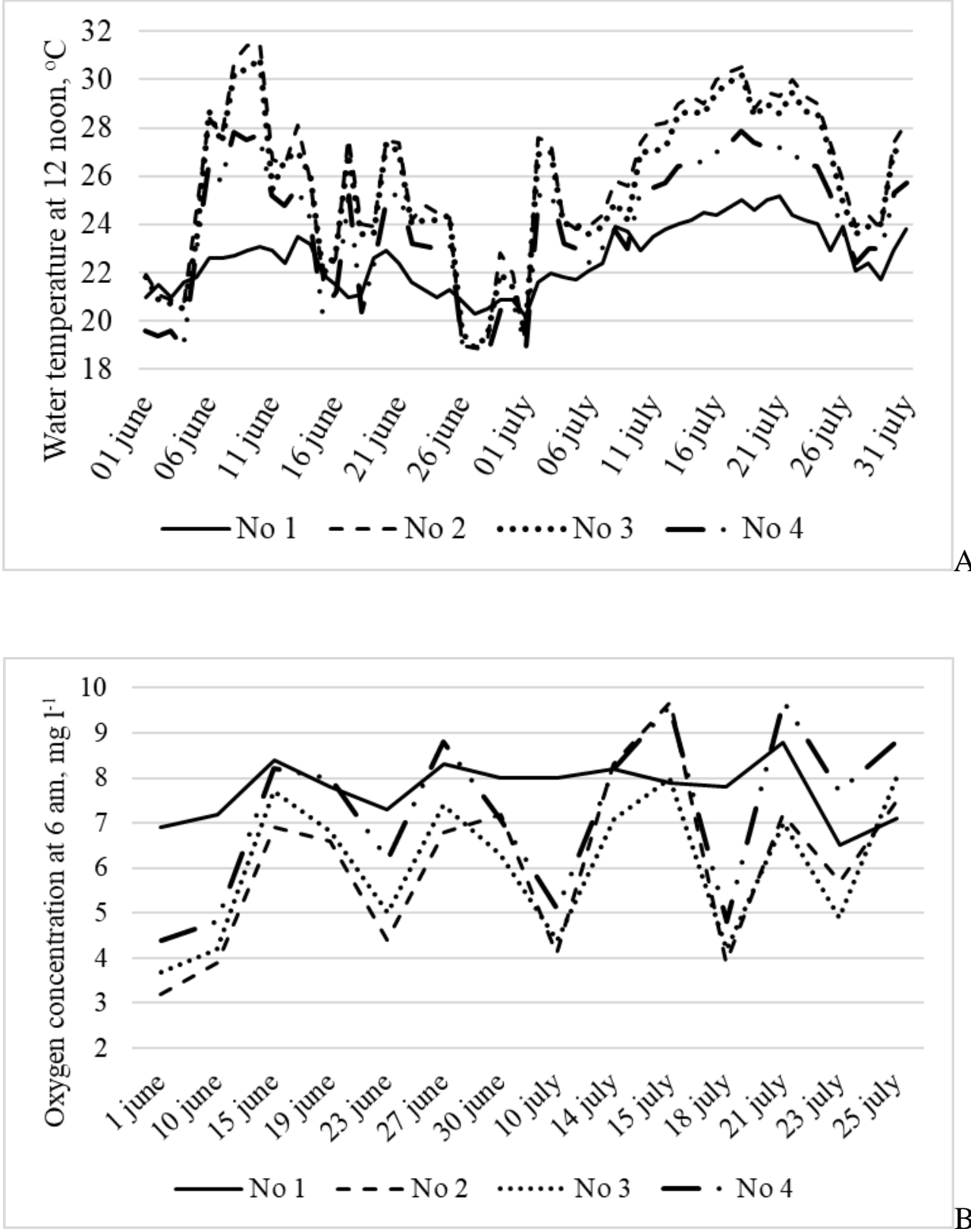

Fig. 1. Temperature (A) and oxygen (B) conditions in experimental water body's

The water bodies No. 2 - No. 4 are shallow water ponds with a depth of up to $1.2 \mathrm{~m}$. The average temperature for June was $24.7^{\circ} \mathrm{C}$ in the second reservoir with oscillations during the month from 19.0 to $31.5^{\circ} \mathrm{C}\left(24.8^{\circ} \mathrm{C}\right)$, in July $-19.2-30.5^{\circ} \mathrm{C}\left(27.2^{\circ} \mathrm{C}\right)$. In the reservoir No. $3-$ June: $18.9-30.0^{\circ} \mathrm{C}\left(24.4^{\circ} \mathrm{C}\right)$, July $-18.9-30.2^{\circ} \mathrm{C}\left(26,7^{\circ} \mathrm{C}\right)$. In the reservoir No. 4 , respectively, the water temperature was $18.9-27.8^{\circ} \mathrm{C}\left(22.9^{\circ} \mathrm{C}\right)$ and $18.9-27.9^{\circ} \mathrm{C}\left(25.1^{\circ} \mathrm{C}\right)$. Water temperature fluctuations in all experimental waters reached $3-5^{\circ} \mathrm{C}$ during the day. The difference in water temperature between experimental ponds increased significantly in the predawn hours.

The most stable temperature was in the control, where no significant fluctuations in 
temperature were observed both during the day and during the month. The average temperature in reservoir No. 4 was higher than in the control, and there were considerable fluctuations during the day. The water temperature in reservoirs No. 2 and 3 was sometimes above $30.0^{\circ} \mathrm{C}$, and its significant difference in reservoirs was only at night and in the morning.

The control reservoir also differed in stable conditions for the oxygen regime. The concentration of dissolved oxygen in water was $6.5-8.8 \mathrm{mg} \cdot \mathrm{L}^{-1}$. In general, the oxygen content was satisfactory in the reservoir No. 4 , where it reached values from 5.1 to $9.7 \mathrm{mg} \cdot \mathrm{L}^{-1}$ in the predawn hours. The most difficult conditions for this indicator were in the reservoir No. 3 , especially in July. The oxygen content ranged from 4.2 to $8.0 \mathrm{mg} \cdot \mathrm{L}^{-1}$ with a predominance of its level from 4.2 to $4.9 \mathrm{mg} \cdot \mathrm{L}^{-1}$. The content of dissolved oxygen at 4 o'clock in the morning was from 3.9 to $9.7 \mathrm{mg} \cdot \mathrm{L}^{-1}$ in reservoir No. 2, and it was largely dominated by 5.7-7.2 $\mathrm{mg} \cdot \mathrm{L}^{-1}$.

Thus, the small storage reservoir was characterized by a stable temperature and oxygen regime. Moderately elevated temperature and satisfactory oxygen conditions were observed in reservoir No. 4. The water temperature significantly prevailed in the climatic norm in other water bodies. The difference in their temperature was insignificant. However, the oxygen conditions in the early morning hours were worse in water body No 3.

There were no significant differences hydrochemical indicators between the studied reservoirs. The $\mathrm{pH}$ of the medium was $8.1-8.3$, water hardness was $5.9-6.3 \mathrm{mg}$-eq. $\cdot \mathrm{L}^{-1}$, the content of calcium ions $-58.2-67.1 \mathrm{mg} \cdot \mathrm{L}^{-1}$, magnesium $-31.8-35.2 \mathrm{mg} \cdot \mathrm{L}^{-1}$, chlorides $29.8-31.2 \mathrm{mg} \cdot \mathrm{L}^{-1}$, phosphorus phosphates $-0.048-0.062 \mathrm{mg} \cdot \mathrm{L}^{-1}$, nitrates $-0.075-0.090 \mathrm{mg}$ $\mathrm{N} \cdot \mathrm{L}^{-1}$.

\subsection{Methods of Biochemical Research}

Fish caught active fishing methods. Their blood was collected from the heart immediately after being caught. Blood plasma was obtained by centrifugation at 5 thousand rpm for 15 minutes. Blood plasma was frozen at $-18^{\circ} \mathrm{C}$. The content of cortisol, prolactin and somatotropin was determined in blood plasma using an enzyme immunoassay analyzer (Rayto RT-2100C) and commercial kits «DS-IFA-Steroid» and «DS-IFA-Prolactin» (NPO Diagnostic Systems, Russia), Human Growth Hormone (hGH) ELISA (Calbiotech, USA). The total content of thyroxine (T4) and triiodothyronine (T3) was determined in the blood plasma using the enzyme immunoassay and commercial kits «T3-ELISA», «T4-ELISA» (NPL Granum Ukraine).

\subsection{Statistical Analysis}

The significance of differences between the mean values of the hormone content was determined with using Student's t-test probability level ( $\mathrm{c}$ 0.05) (Rokitskyi 1973). The statistical data was processed with Statistica 5.5. All bioethical norms were observed throughout the experiment. 


\section{1) Macrothink}

\section{Results}

Research have shown that most of the studied fish species in June react to increased and fluctuating temperature conditions of water bodies with an increase in the content of cortisol in the blood plasma. At the same time, perch and roach are most sensitive to the action of this factor. The amount of cortisol in their blood increases at a maximum temperature of 3.4 and 2.2 times, respectively, compared with the conditional control (Fig. 2). Only carp responds to the increase in temperature regime by reducing the content of cortisol in the blood plasma. Perch and ruff are fully adapted to the new conditions of existence in July, and the content of cortisol in the blood is significantly reduced compared with June. Roach and rudd reveal no significant differences in blood cortisol levels in June and July. However, they react to a rise in water temperature or a slight up to $30 \%$ decrease in the hormone content (roach) or a slight increase up to $11 \%$ (rudd) compared to the control. Carp continues to respond to rising water temperatures in its own way in July. The level of cortisol in it increases with a rise in the average temperature to $26.7^{\circ} \mathrm{C}$. A decrease in the content of cortisol in his blood is observed with a further increase in temperature to $27.2^{\circ} \mathrm{C}$.

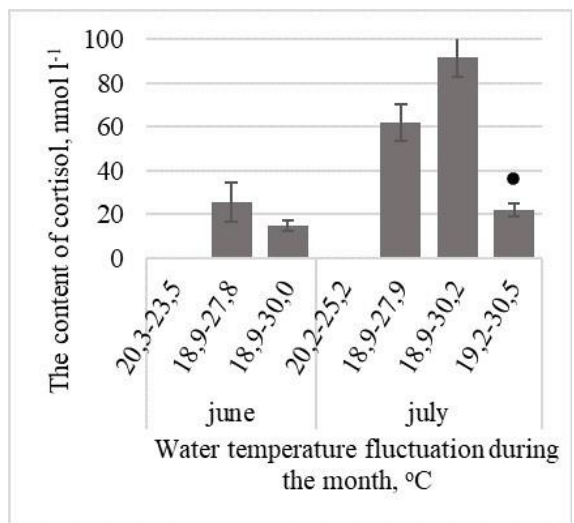

A

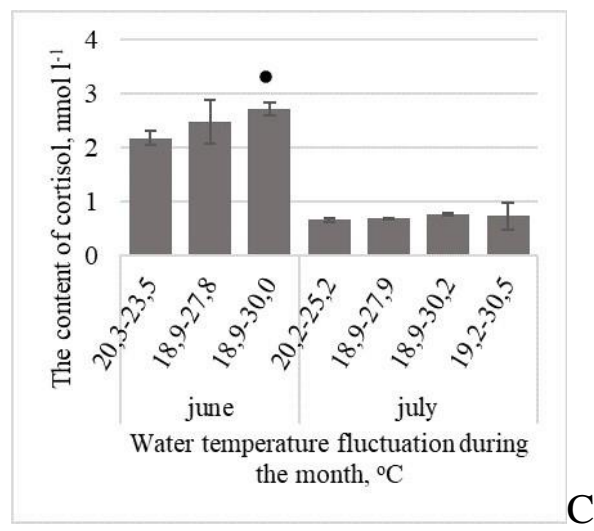

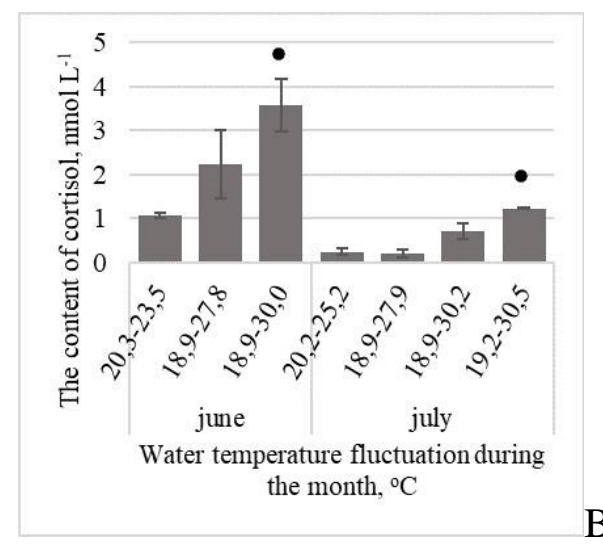

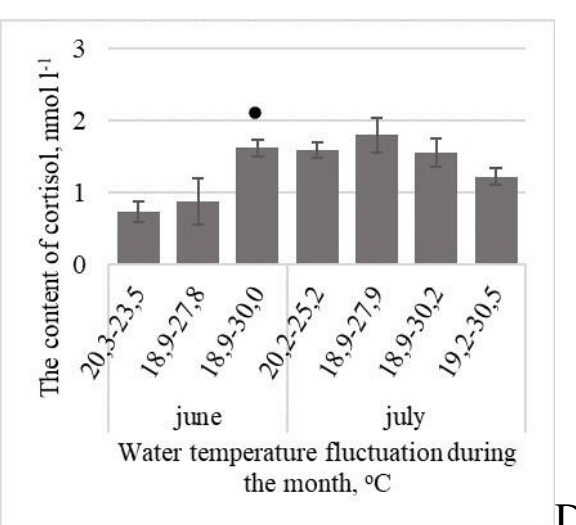




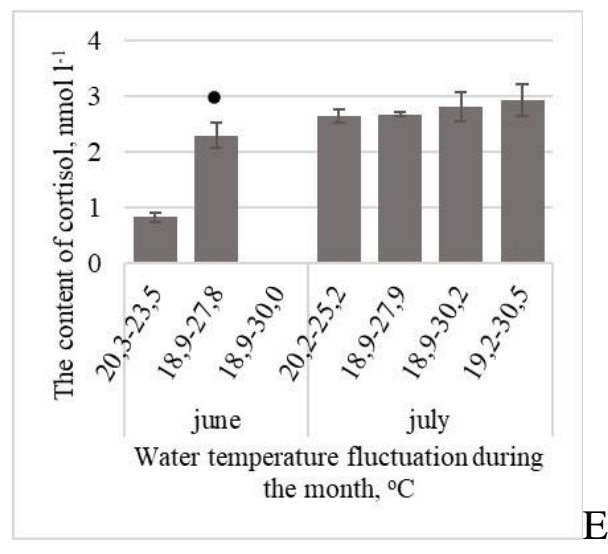

Fig. 2. The content of cortisol in the blood plasma of fish under various environmental conditions, $\mathrm{n}=6$

Note: A - carp, B - perch, C - ruff, D - roach, E - rudd; $\bullet-p<0.05$.

The content of thyroxin in the blood increases with a rise in the temperature regime of the reservoir against the background of a slight decrease in the oxygen concentration in water in all studied fish species (Fig. 3). The content of thyroxin in the blood decreased in perch in July compared with June, while maintaining the tendency of its growth with increasing temperature. This indicator did not significantly differ at various temperatures in July at roach.
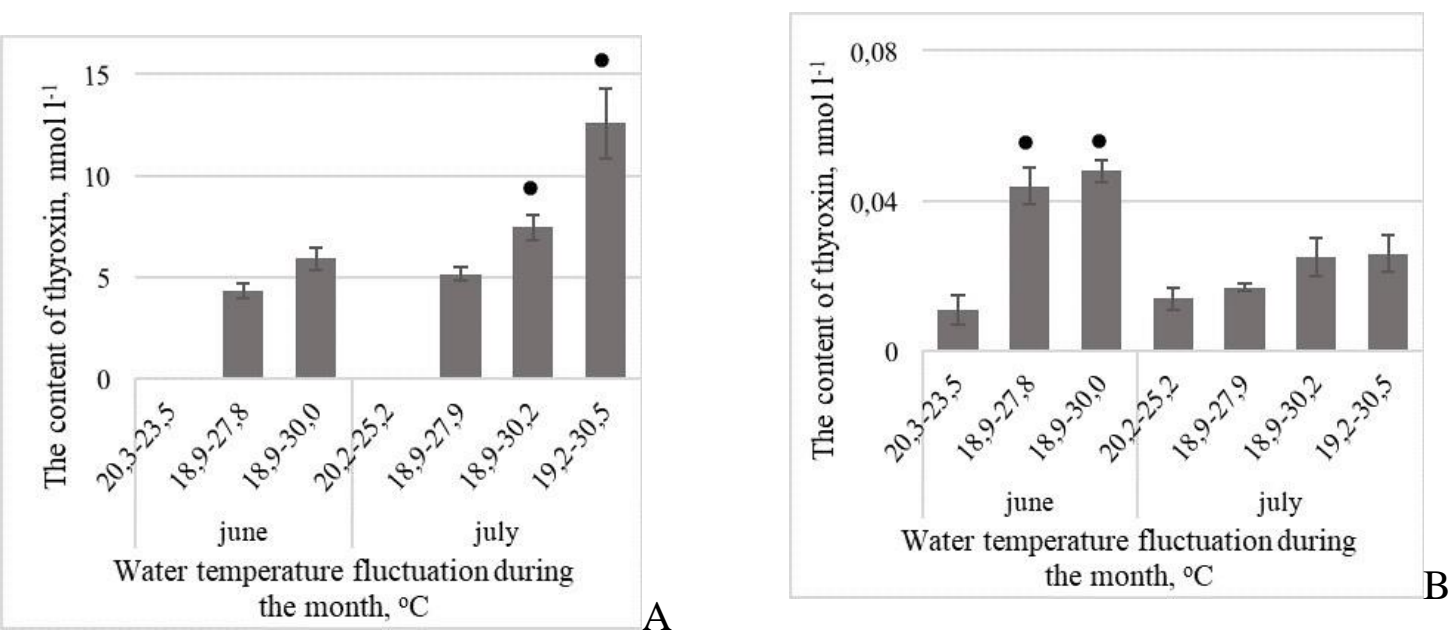

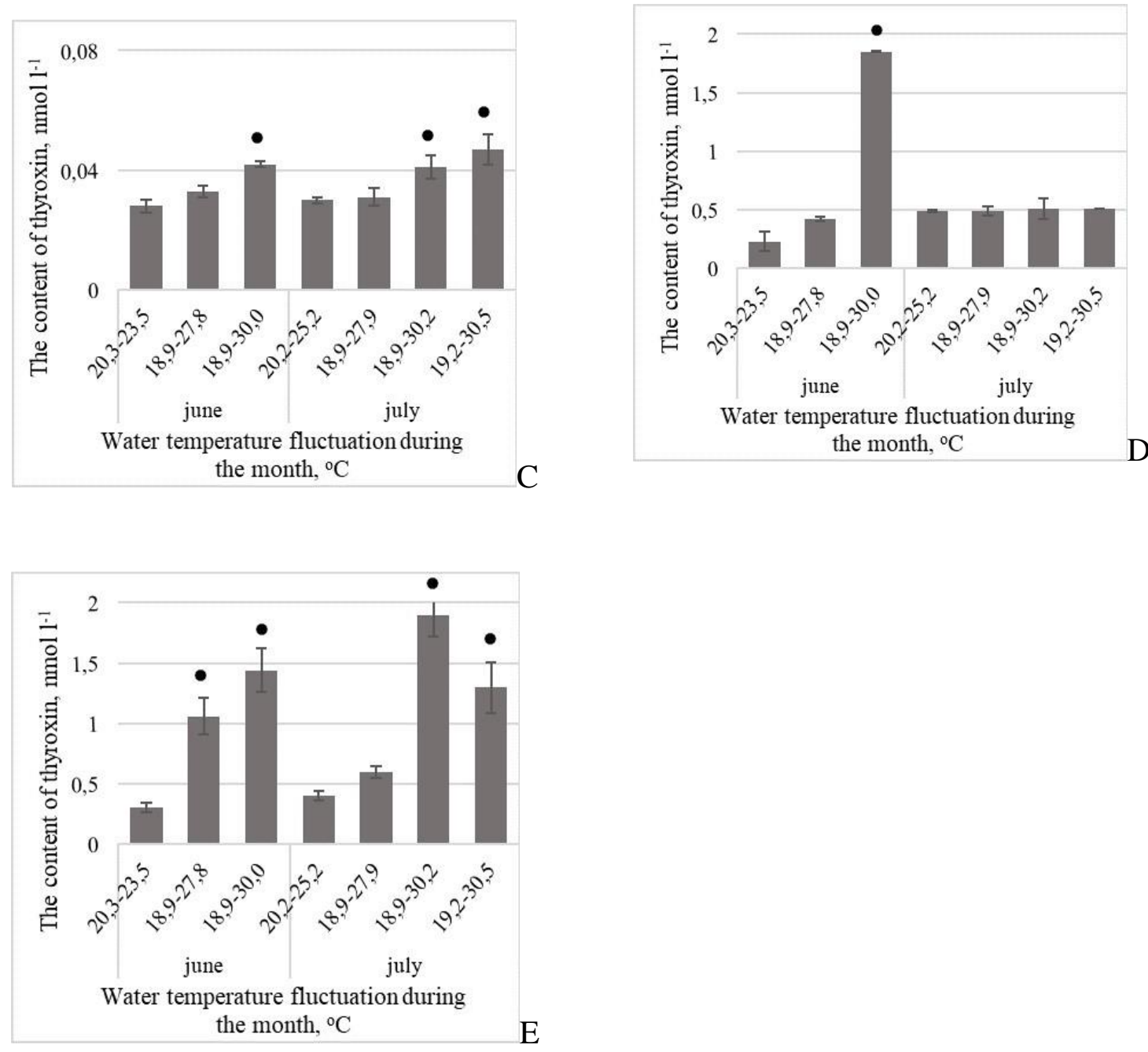

Fig. 3. The content of thyroxin in the blood plasma of fish under various environmental conditions, $n=6$

Note: A - carp, B - perch, C - ruff, D - roach, E - rudd; $\bullet-p<0.05$.

Triiodothyronine is a more active form of thyroid hormones compared with thyronine. The change in its content is species specific under the action of temperature. Carp, ruff and roach are characterized by a decrease in the level of the hormone with an increase in water temperature in June, rudd - an increase (Fig. 4). The influence of other factors on this indicator of blood in the perch is noted. Fish also responded species-specific to elevated and fluctuating temperature conditions in July. Namely, the content of triiodothyronine in the blood plasma increases in ruff, roach, and rudd with increasing water temperature, while in carp and perch it decreases. 

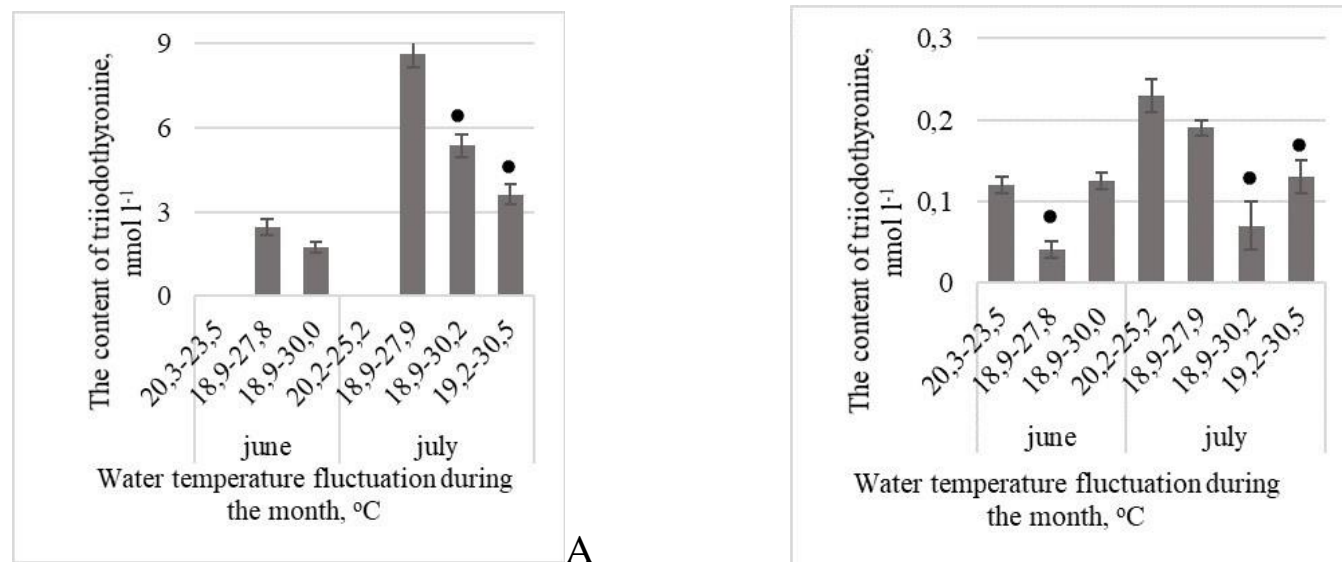

Water temperature fluctuation during the month, ${ }^{\circ} \mathrm{C}$
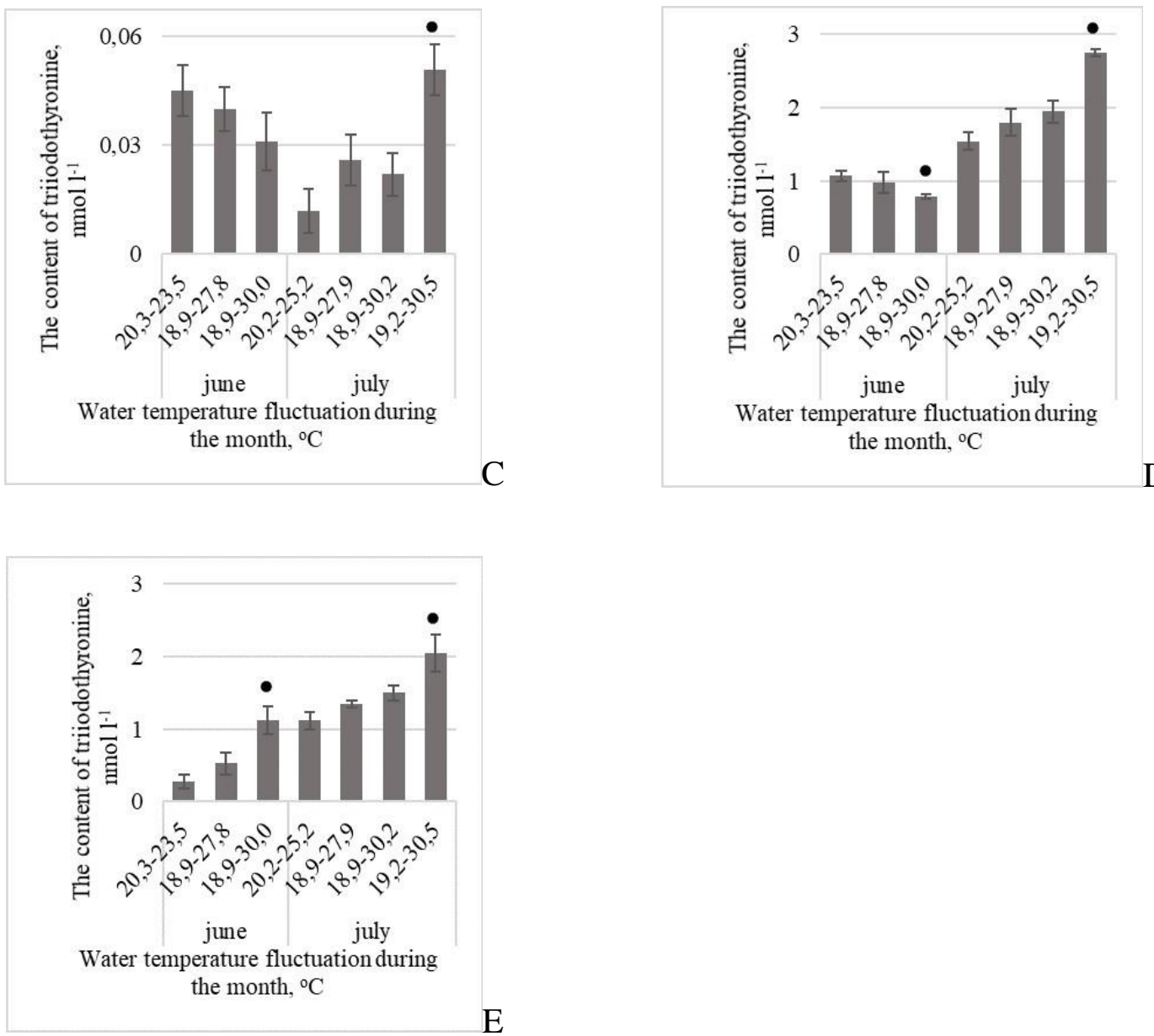

Fig. 4. The content of triiodothyronine in the blood plasma of fish under various environmental conditions, $\mathrm{n}=6$

Note: $\mathrm{A}-$ carp, $\mathrm{B}-$ perch, $\mathrm{C}-$ ruff, $\mathrm{D}-$ roach, $\mathrm{E}-$ rudd; $\bullet-\mathrm{p}<0.05$.

It should be noted that the content of somatotropin in the blood plasma of all studied fish significantly decreases with increasing water temperature during the month and with its daily fluctuations. This is especially characteristic of a perch with an increase in water temperature 


\section{Macrothink}

to $30.5^{\circ} \mathrm{C}$, the content of somatotropin in its blood decreases in June by 9.9 times, in July 6.4 times compared with a stable temperature regime of $20.3-25.2^{\circ} \mathrm{C}$ (Fig. 5).
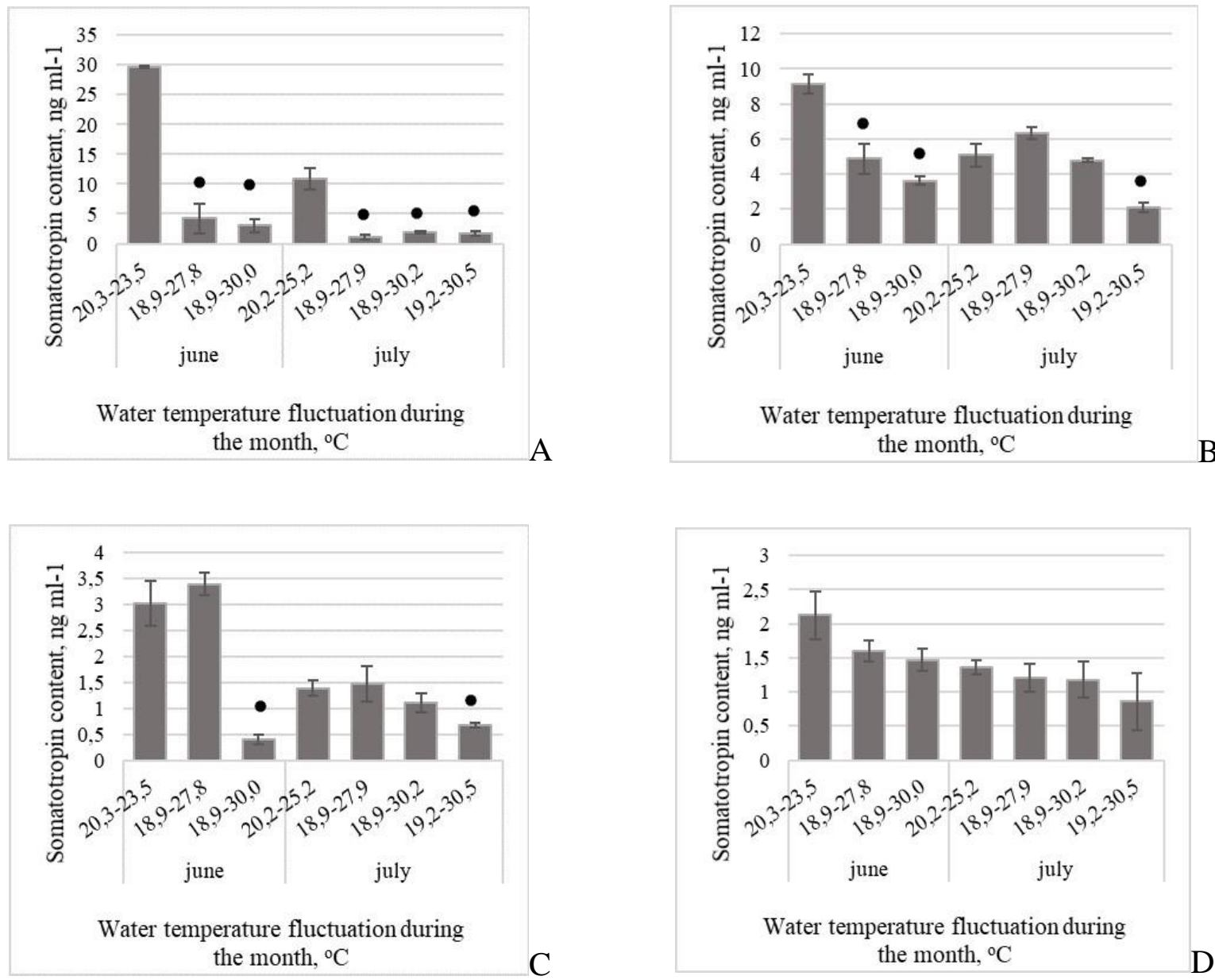

Fig. 5. Content of somatotropin in blood plasma of fish at various environmental conditions of existence, $n=6$

Note: A - perch, B - ruff, C - roach, D - rudd; $\bullet-\mathrm{p}<0.05$.

Similarly, the content of prolactin in the blood plasma of fish changes under the action of elevated water temperature and a reduced concentration of dissolved oxygen (Fig. 6). 

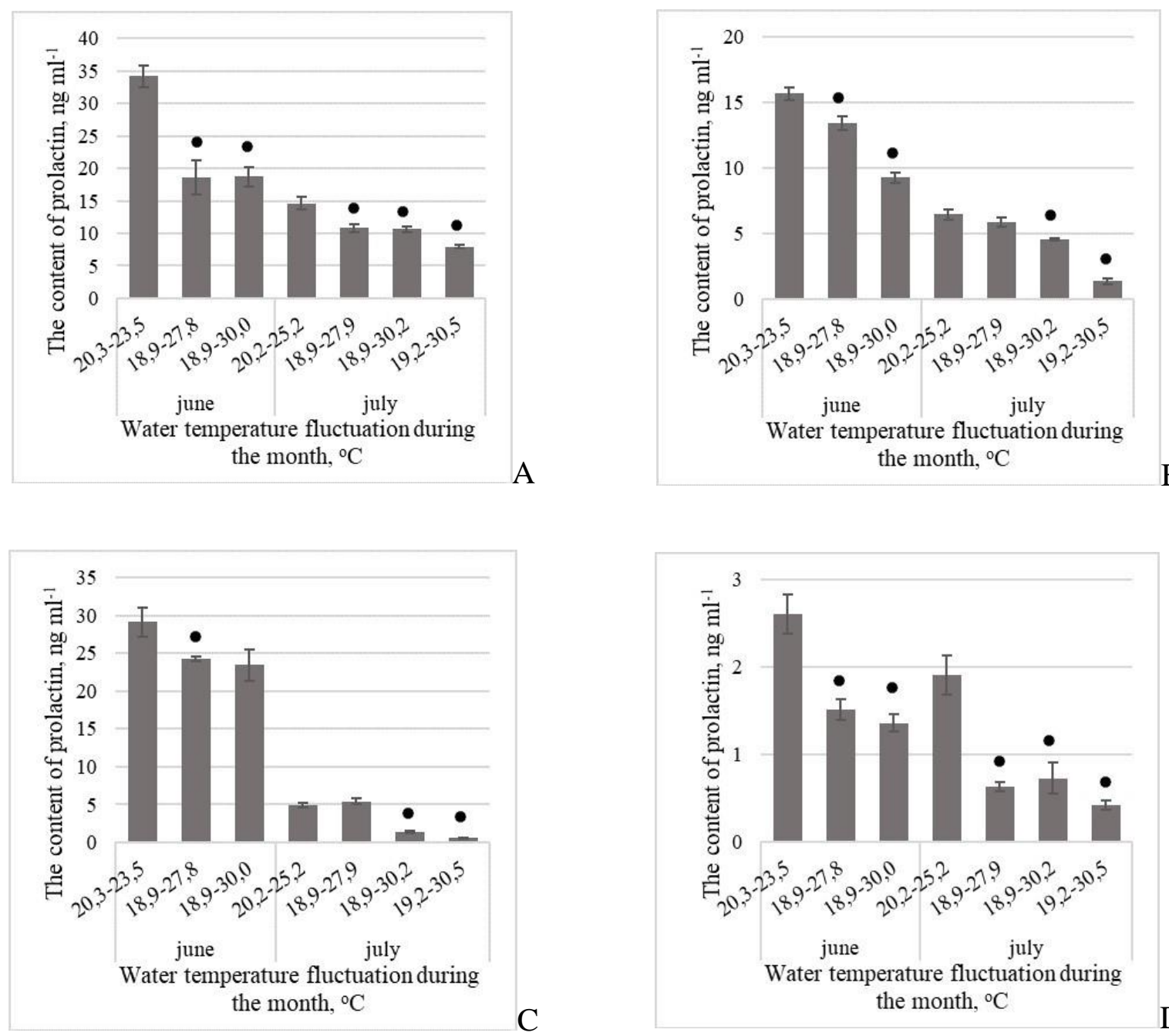

Fig. 6. The content of prolactin in the blood plasma of fish in different environmental conditions of existence, $n=6$

Note: A - perch, B - ruff, C - roach, D - rudd; $\bullet-\mathrm{p}<0.05$.

\section{Discussion}

The nature of the hormonal response of fish to environmental factors depends on the biology of the species. It has been established that the content of cortisol in the ruff blood plasma does not change under the influence of the temperature-oxygen conditions of the water body. Ruff lives in the lower layer of water with less temperature fluctuations and is not exposed to this stress factor (Hölker, Thiel 1998). This species is more resistant to reducing the dissolved oxygen content in water. An increase in blood cortisol indicates a worsening of living conditions.

Another group of fish (perch, roach, and rudd) responds to the oscillatory regime of temperature and dissolved oxygen in June by a sharp increase in the level of cortisol in the blood. The main role in the growth of this hormone is played by the temperature factor, and 
not the concentration of dissolved oxygen in water. In July, only the perch, as the most cold-water species of the studied fish species, reacted in a similar way. Moreover, this occurred in the perch with a significantly lower level of cortisol, both in the control and in the experiment. The content of cortisol in the rudd blood plasma increased in July compared with June, the differences of this indicator among different groups of fish were not significant. The roach reacted more to a lower water temperature. This indicates that this species has fully adapted to the summer conditions of existence.

Carp differed from other fish species in the nature of changes in plasma cortisol content. Increased water temperature is more favorable for him. The carp reacts by increasing the plasma cortisol content only to a decrease in the dissolved oxygen content.

The overall activity of the passage of metabolic processes can be assessed by the content of thyroid hormones in the blood plasma of fish (Dolomatov et al. 2013). According to our research, for all species of fish there is a direct relationship between the total content of thyroxin and the average daily temperature in the water body. The highest content of thyroxin is observed in carp from 4.2 to $12.3 \mathrm{nmol} \cdot \mathrm{L}^{-1}$, in roach and rudd from 0.3 to $1.8 \mathrm{nmol} \cdot \mathrm{L}^{-1}$. The lowest content of thyroxin from 0.01 to $0.06 \mathrm{nmol} \cdot \mathrm{L}^{-1}$ is observed in the blood plasma of predatory fish species (perch and ruff). We note an increase in the total metabolic activity (in terms of thyroxin content) with a lower concentration of dissolved oxygen in water only for the rudd.

Interspecific differences in the content of triiodothyronine in the blood are the same as for thyroxin. Among the fish species studied, the maximum content of triiodothyronine was in carp $-1.8-8.7 \mathrm{nmol} \cdot \mathrm{L}^{-1}$, average in rudd and roach $-0.5-2.2 \mathrm{nmol} \cdot \mathrm{L}^{-1}$, and in predatory fish the minimum $-0.02-0.18 \mathrm{nmol} \cdot \mathrm{L}^{-1}$. A direct relationship between the water temperature and the content of triiodothyronine in the blood plasma is noted only for rudd and roach. The opposite relationship between these indicators is marked for carp and ruff. Only perch reacts negatively to a decrease in the content of dissolved oxygen in water.

Somatotropin in fish enhances the growth of muscle and bone tissue, regulates the metabolism of proteins, carbohydrates, fats, calcium, phosphorus and nitrogen in the tissues (Davidson 1987, Yousefian 2011). It is able to mobilize spare lipids and increase fat oxidation, which leads to a decrease in the peripheral use of carbohydrates, thereby increasing blood sugar levels (Sangiao-Alvarellos et al. 2003). We have shown interspecies differences in the content of this hormone in the blood plasma of fish. Obviously this is due to the species-specific features of the functioning of the pituitary of these fish. It draws attention that a higher content of hormone in the blood of fish is observed at normal temperature conditions of the water body compared with those that were in conditions of elevated water temperature. Thus, the content of somatotropin in acceptable conditions in roach, perch and ruff was higher in 6.1; 6.8 and 2.6 times in June than in fish from water bodies, in which the water temperature periodically reached $29.3^{\circ} \mathrm{C}$. This pattern is reversed for the ruff in July. In particular, this is expressed in the equal content of this hormone in fish with stable and oscillatory temperature conditions. Obviously, this is due to an increase in the rate of growth of this species during this period. Feeding the ruff is more effective in low light, in our case, 
this is due to the increased development of algae and reduced water clarity (Hölker, Thiel 1998). The number and diversity of benthic organisms (the basis of nutrition of this species) increases in response to the growth of the synthesis of new organic substances in water bodies.

However, the content of somatotropin in the blood plasma of all fish species decreases in July with increasing water temperature. By reducing the content of somatotropin, which regulates the main energy processes, less energy-intensive substances are used to maintain the homeostasis of the body with increasing water temperature. Water temperature plays a direct role in the regulation of the content and synthesis of this pituitary hormone. Elevated levels of somatotropin in the blood plasma under normal temperature conditions may be associated with significant lipid costs of high fish growth rates. This is confirmed by the fact that the weight and length of the fish were large with stable temperature conditions corresponding to climatic norms as compared with altered temperature conditions.

It is known that somatotropin, along with prolactin, is involved in the regulation of the formation of germ cells in most fish (Yousefian 2011). Considering that the temperature optimum for fish species with a low oxygen concentration in the early morning hours was observed in experimental reservoirs, their fluctuations had a significant effect on the intensity of feeding, the general physiological state of fish, the activity of metabolism and the formation of oocytes in females. The optimal temperature and oxygen conditions in the reservoir are manifested in an increased level of somatotropin in the blood plasma of fish, which has a positive effect on the intensity of their growth. Thus, according to the level of somatotropin, which is involved in the regulation of many physiological processes, in particular, in the metabolism of lipids, proteins, carbohydrates and ions (Yousefian 2011), one can judge the ability of various fish species to biochemical adaptation under the influence of environmental factors caused by climate change.

Prolactin in fish regulates the processes of ionic and lipid metabolism. It is known that it is actively involved in the regulation of thermal homeostasis in aquatic animals through the synthesis and distribution of lipids in body tissues (Sautin 1986). The synthesis and release of prolactin into the blood is activated in fish under hypoosmotic conditions (Manzon 2002). Prolactin regulates the water-salt balance, which, in turn, causes changes in the growth and development of fish. Metabolism, behavior, reproduction and activity of the immune system are changed under the influence of this hormone (Weber, Grau 1999, Harris et al. 2004).

We found that the content of this hormone in the blood of all fish decreased significantly with increasing temperature. The content of prolactin in the blood plasma of roach, perch, and ruff was higher by $1.2,1.15$, and 2.6 times under normal temperature conditions compared to fish that were at elevated temperatures.

It is noteworthy that the content of prolactin significantly decreases in July, which is obviously due to its participation in the regulation of lipid metabolism, aimed at the growth of fish. Moreover, the content of this hormone in the blood plasma of fish was significantly lower with excessive temperature conditions of the water body. This fact is explained by the studies of Yu. Yu. Sautin, who proved the importance of prolactin in the acclimation of fish to 
changes in ambient temperature (Sautin 1986). In addition, this hormone regulates both the metabolism of lipids and amino acids, and energy processes. Since acclimation to the existing factors is quite an energy-consuming mechanism, fish need additional preservation of energy resources for growth potential with a change in water temperature, which is regulated by a lower content of prolactin into the blood.

Rudd had a low content of prolactin, perch had the highest content, which indicates the existence of species specificity in its synthesis. The greatest variability of this indicator was observed in perch and roach compared with other studied species. This is probably due to their metabolic and behavioral patterns.

\section{Conclusions}

The nature of the hormonal response to the current environmental factors depends on the biology of a particular species. The increase in the content of cortisol in the blood primarily indicates the presence of stress phenomena in fish. The studied fish can be divided into four conditional groups according to the change in the content of cortisol in the blood in response to the action of elevated water temperature: the rudd is practically unresponsive to this factor; perch is constantly under stress; roach and ruff - able to adapt to this factor; carp - tolerates a rise in water temperature.

The content of thyroid hormones in the blood of fish increases under the influence of atypical, oscillatory and elevated temperature conditions, which indicates an increased activity of metabolic processes.

The content of somatotropin in the blood plasma of fish decreases under the influence of water temperature, which exceeds the optimum for a particular species. This can slow the growth rate of fish in the summer.

The content of prolactin in the blood of all studied fish species decreases with increasing temperature, which indicates its participation in the processes of adaptation of fish to unusual conditions. This phenomenon is probably related to the processes of conservation of energy resources in the process of adapting fish to the operating factors.

\section{References}

Comte, L., \& Olden, J. D. (2017). Climatic vulnerability of the world's freshwater and marine fishes. Nature Climate Change, 7, 718-722. https://doi.org/10.1038/nclimate3382

Davidson, M. B. (1987). Effect of growth hormone on carbohydrate and lipid metabolism. Endocrine Reviews, 8(2), 115-231. https://doi.org/10.1210/edrv-8-2-115

Dolomatov, S. I., Kubyshkin, A. V., Kutia, S. A., \& Zukow, W. (2013). Role of thyroid hormones in fishes. Journal of Health Sciences, 3(9), 279-296.

Goldspink, G. (1995). Adaptation of fish to different environmental temperature by qualitative and quantitative changes in gene expression. Journal of Thermal Biology, 20(1-2), 167-174. https://doi.org/10.1016/0306-4565(94)00045-K 


\section{Ml Macrothink}

Handeland, S. O., Imsland, A. K., \& Stefansson, S. O. (2008). The effect of temperature and fish size on growth, feed intake, food conversion efficiency and stomach evacuation rate of Atlantic salmon post-smolts. Aquaculture, 283, 36-42.

https://doi.org/10.1016/j.aquaculture.2008.06.042

Harris, J., Stanford, P. M., Oakes, S. R., \& Ormandy, C. J. (2004). Prolactin and the prolactin receptor: new target of an old hormone. Annals in Medicine, 36(6), 414-426.

https://doi.org/10.1080/07853890410033892

Hölker, F., \& Thiel, R. (1998). Biology of Ruffe (Gymnocephalus cernuus (L.)). A Review of Selected Aspects from European Literature. Journal of Great Lakes Research, 24(2), 186-204. https://doi.org/10.1016/S0380-1330(98)70812-3

Jobling, M. (1981). Temperature tolerance and the final preferendum-rapid methods for the assessment of optimum growth temperature. Journal of Fish Biology, 19(4), 439-455. https://doi.org/10.1111/j.1095-8649.1981.tb05847.x

Klyashtorin, L. B., \& Lyubushin, A. A. (2007). Cyclic climate changes and fish productivity. Moscow VNIRO publishing

Konstantinov, A. S., Pushkar, V. Y., \& Averyanova, O. V. (2003). The effect of fluctuations in abiotic factors on the metabolism of some hydrobionts. News of the Russian Academy of Sciences. Biological series, 6, 729-734 (in Russian).

https://doi.org/10.1023/B:BIBU.0000007719.82974.44

Little, A. G., Kunisue, T., Kannan, K., \& Seebacher, F. (2013). Thyroid hormone actions are temperature-specific and regulate thermal acclimation in zebrafish (Danio rerio). BMC Biology, 11, 26. https://doi.org/10.1186/1741-7007-11-26

Malinin, L. K., Bazarov, M. I., Golovanov, V. K., \& Linnik, V. D. (1996). Effect of water temperature on the range of daily vertical migrations of fish. Behavior and distribution of fish, Borok, 103-118 (in Russian)

Manzon, L. A. (2002). The Role of prolactin in fish Osmoregulation: A Review. General and Comparative Endocrinology, 125(2), 291-310. https://doi.org/10.1006/gcen.2001.7746

McCormick, S. D. (2011). The Hormonal Control of Osmoregulation in Teleost Fish. Encyclopedia of Fish Physiology: From Genome to Environment, San Diego: Academic Press, 2, 1466-1473. https://doi.org/10.1016/B978-0-12-374553-8.00212-4

McCormick, S. D., \& Bradshaw, D. (2006). Hormonal control of salt and water balance in vertebrates. General and Comparative Endocrinology, 147(1), 2-8.

https://doi.org/10.1016/j.ygcen.2005.12.009

Movchan, Y. V. (2011). Fish of Ukraine. Kiev: National Academy of Sciences of Ukraine (in Ukraine)

Nemova, N. N., \& Vysotskaya, R. U. (2004). Biochemical indication of the status of fish. Moscow: Science (in Russian) 


\section{Al Macrothink}

Aquatic Science and Technology

ISSN 2168-9148

2019, Vol. 7, No. 2

Nilsson, G. E., \& Lefevre, S. (2016). Physiological Challenges to Fishes in a Warmer and Acidified Future. Physiology, 31(6), 409-417. https://doi.org/10.1152/physiol.00055.2015

Ogorodnikova, A. A., Shcheglov, V. V., \& Weideman, E. L. (2004). The model of "impact state - response" in solving the tasks of environmental monitoring of pollution of coastal ecosystems. News of the Pacific Fisheries Research Center, 137, 321-336 (in Russian)

Rokitskyi P. F. (1973). Biological statistics. Minsk: High School (in Russian)

Sangiao-Alvarellos, S., Laiz-Carrión, R., Guzmán, J. M., Martin del Río, M. P., Miguez, J. M., Mancera, J. M., \& Soengas, J. L. (2003). Acclimation of S. auratato various salinities alters energy metabolism of osmoregulatory and nonosmoregulatory organs. American Journal of Physiology-Regulatory, Integrative and Comparative Physiology, 285(4), 897-907.

https://doi.org/10.1152/ajpregu.00161.2003

Sautin, Y. Y. (1986). On the involvement of prolactin-like pituitary hormone in the control of energy and structural lipids with changes in temperature conditions. Energy metabolism in fish. Moscow, 57 (in Russian)

Vinagrea, C., Madeiraa, D., Narcisob, L., Cabrala, H. N., \& Diniz, M. (2012). Effect of temperature on oxidative stress in fish: Lipid peroxidation and catalase activity in the muscle of juvenile seabass, Dicentrarchus labrax. Ecological Indicators, 23, 274-279.

https://doi.org/10.1016/j.ecolind.2012.04.009

Weber, G. M., \& Grau, E. G. (1999). Changes in serum concentrations and pituitary content of the two prolactins and growth hormone during the reproductive cycle in female tilapia, Oreochromis mossambicus, compared with changes during fasting. Comparative Biochemistry and Physiology. Part C: Pharmacology, Toxicology and Endocrinology, 124(3), 323-335. https://doi.org/10.1016/S0742-8413(99)00081-X

Xia, R., Zhang, Y., Critto, A., Wu, J. J., Fan, J. T., Zheng, Z. R., \& Zhang, Y. Z. (2016). The Potential Impacts of Climate Change Factors on Freshwater Eutrophication: Implications for Research and Countermeasures of Water Management in China. Sustainability, 8(229), 1-17. https://doi.org/10.3390/su8030229

Yadav, M. (2008). Fish endocrinology. Sachin Printers, Delhi

Yousefian, M. S. E. (2011). The review of the effect of growth hormone on immune system, metabolism and osmoregulation of fish. Australian Journal of Basic and Applied Sciences, $5(5), 467-475$.

\section{Copyrights}

Copyright for this article is retained by the author(s), with first publication rights granted to the journal.

This is an open-access article distributed under the terms and conditions of the Creative Commons Attribution license (http://creativecommons.org/licenses/by/4.0/) 